\title{
PENGARUH LATIHAN FISIK AEROBIK DENGAN INTENSITAS SEDANG TERHADAP KONDISI MAKROSKOPIK DAN GAMBARAN HISTOPATOLOGI MIOKARD MENCIT BALB/C
}

\author{
Niswan Helja Batubara ${ }^{1}$, Nova Sylviana ${ }^{1,2,3}$, Hasrayati Agustina ${ }^{4}$, \\ Hadaral Hudanul Qolbi ${ }^{1}$ \\ ${ }^{1}$ Laboratorium Hewan, Fakultas Kedokteran, Universitas Padjadjaran, \\ ${ }^{2}$ Departemen Anatomi, Fisiologi, dan Biologi Sel, Fakultas Kedokteran, Universitas Padjadjaran, \\ ${ }^{3}$ Laboratorium Fisiologi Molekular, Laboratorium Sentral Universitas Padjadjaran, \\ ${ }^{4}$ Departemen Patologi Anatomi, Rumah Sakit Umum Pusat Dr. Hasan Sadikin Bandung
}

\begin{abstract}
Cardiovascular diseases is one of the non-communicable diseases that has been the leading cause of death compared to other causes. Actually, cardiovascular diseases can be prevented with avoiding the risk factors and lifestyle improvements such as doing physical exercise. Useful physical exercise according to according to The American College of Cardiology/American Heart Association (ACC/AHA) is a moderate intensity aerobic exercise conducted 30 minutes in time for 5 days a week. This research aims to study the effects of moderate intensity aerobic exercise on macroscopic conditions, histopathologic features of the myocardium of mice. This research using 35 male balb/c mice devided to 3 groups (control, physical activity, exercise). Variables in this research included duration of physical activity and exercise, macroscopic conditions, histopathologic features of the myocardium of balb/c mice. After 10 and 28 days of exposure, the heart were harvested. The macroscopic conditions, histopathologic features of the myocardium were examined. The weight of heart in physical activity group was greater than control group $(\mathrm{p}=0.009)$. Similarly, the weight of heart exercise group was also greater compared to control group $(\mathrm{p}=0.013)$. The histopathologic features in physical activity and physical exercise groups showed pathological features of myocardial infarction $(\mathrm{p}=0.242)$. While in the control group did not show pathological features. Aerobic physical activity moderate intensity increase the risk of pathological condition of heart in the form of myocardial infarct through the macroscopic conditions and histological features of myocardium. Meanwhile, exercise with moderate intensity affect the physiological hypertrophy of the myocardium.
\end{abstract}

Keywords: aerobic physical activity, moderate intensity, macroscopic conditions, histopathologic features of the myocardium

Korespondensi: Niswan Helja Batubara, E-mail: niswan.helja10@gmail.com, Departemen Anatomi, Fisiologi, dan Biologi Sel, Fakultas Kedokteran Universitas Padjadjaran. Jalan Raya Jatinangor Km 21, Sumedang, Jawa Barat, Indonesia. 


\section{PENDAHULUAN}

Penyakit tidak menular (NonCommunicable Disease atau NCD) merupakan salah satu penyakit yang tergolong dalam masalah kesehatan utama serta menjadi tantangan tersendiri bagi dunia. Penyakit non komunikabel pada tahun 2012 telah menyebabkan angka kematian sebanyak $68 \%$ atau sekitar 38 juta kasus dari 56 juta kasus kematian di dunia. Sebanyak 5,8 juta kasus kematian akibat penyakit non komunikabel tersebut berada di regio Asia Tenggara ${ }^{1}$.

Penyakit kardiovaskular merupakan salah satu contoh penyakit non komunikabel yang telah menjadi penyebab kematian terbanyak di dunia dibandingkan dengan penyebab-penyebab lainnya. Begitu pula di Indonesia, jumlah kasus kematian akibat penyakit kardiovaskular menurut WHO pada tahun 2014 mencapai $37 \%$ dari total kasus kematian di Indonesia. Angka ini menjadikan kematian akibat penyakit kardiovaskular menjadi penyebab nomor satu kematian akibat penyakit non komunikabel di Indonesia $^{2,3}$.

Penyakit kardiovaskular sebenarnya dapat dicegah dengan menghindari faktor risiko dan perbaikan gaya hidup baik dari aspek asupan nutrisi, mengurangi konsumsi rokok, dan melakukan latihan fisik ${ }^{2}$. Latihan fisik yang bermanfaat menurut The American College of Cardiology/American Heart Association (ACC/AHA) adalah latihan fisik aerobik intensitas sedang yang dilakukan sekurangkurangnya sekitar 30 menit selama minimal 5 hari dalam seminggu 4 .

Selain bermanfaat untuk mencegah timbulnya penyakit, latihan fisik aerobik juga dapat menjadi faktor pola hidup dalam positive health-promoting behavior untuk penyakit yang berhubungan dengan sistem kardiovaskular. Oleh karenanya, promosi kesehatan berupa latihan fisik (sebagai terapi nonfarmakologis) kepada pasien penderita penyakit kardiovaskular oleh tenaga kesehatan sangat dipertimbangkan selain meresepkan terapi farmakologis berupa obatobatan ${ }^{5}$.

Beberapa penelitian menunjukkan dengan jelas bahwa latihan fisik aerobik yang bersifat kronik meningkatkan fungsi kesehatan sistem kardiovaskular, tidak hanya pada subjek penelitian yang sehat tanpa faktor risiko namun juga pada subjek dengan faktor risiko seperti usia, dan faktor risiko penyakit kardiovaskular lainnya ${ }^{6}$.

Namun, pada penelitian lain menunjukkan gambaran yang patologis pada miokardium setelah aktifitas fisik aerobik akut yaitu terjadinya hipertrofi miokard pada hari ke-3, gambaran iskemik miokard pada hari ke-7, dan gambaran infark miokard pada hari ke- $10^{9}$.

Dari beberapa penelitian yang telah disebutkan diatas, dapat disimpulkan bahwa dengan olahraga teratur berupa latihan fisik yang bersifat aerobik dengan durasi yang panjang hanya menimbulkan perubahan fisiologis pada jantung tanpa munculnya kondisi patologis atau tidak menimbulkan kecenderungan yang merugikan pada jantung ${ }^{7,8}$. Sedangkan dengan aktifitas fisik tidak menunjukkan perubahan fisiologis, bahkan menunjukkan potensi yang merugikan seperti gambaran histopatologi iskemia dan infark miokardium. Oleh karena tersebut, maka dilakukan penelitian untuk mengetahui pengaruh dari latihan fisik aerobik dengan intensitas sedang terhadap kondisi makroskopik dan gambaran histopatologi pada miokardium mencit balb/C.

\section{METODE}

Penelitian ini bersifat metode eksperimental laboratoris (laboratory experiment) dan telah memperoleh persetujuan oleh Komite Etik Penelitian Fakultas Kedokteran Universitas Padjadjaran. Segala usaha telah dilaksanakan untuk mengurangi penderitaan hewan coba selama masa penelitian. Subjek penelitian adalah sebanyak 35 ekor mencit jantan (Mus musculus) usia 6-8 minggu dengan berat sekitar 20-30 gram. Mencit diperoleh dari Laboratorium Farmakologi, Fakultas Kedokteran Universitas Padjadjaran. Mencit dikondisikan dalam ruang dengan perbandingan gelap-terang sebanyak 12/12 jam dengan minum dan makanan standar yang cukup. Mencit diadaptasikan selama tujuh hari sebelum penelitian. Mencit dibagi kedalam tiga grup berdasarkan lama perlakuan. Kelompok I (kontrol), kelompok II diberikan perlakuan berupa berenang selama 30 menit sehari 5 hari seminggu selama 10 hari, kelompok III diberikan perlakuan berupa berenang selama 30 menit sehari 5 hari seminggu selama 28 hari. 


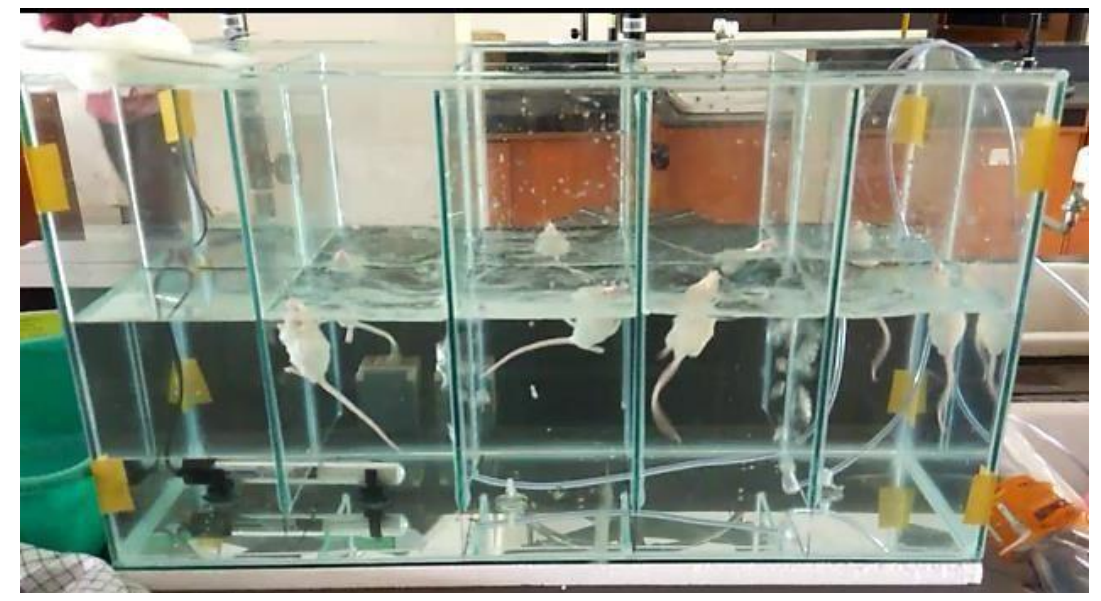

Gambar 1. Perlakuan berupa berenang selama 30 menit sehari 5 hari seminggu selama 10 hari untuk kelompok aktifitas fisik dan 28 hari untuk latihan fisik.

Mencit diberenangkan dalam kolam berukuran $60 \mathrm{~cm} \times 30 \mathrm{~cm}$ x $40 \mathrm{~cm}$ dan dibagi menjadi ruang-ruang kecil berukuran $15 \mathrm{~cm} \times 15$ $\mathrm{cm}$ untuk setiap mencit. Kolam renang juga dihangatkan sampai mencapai suhu $32^{0}$ Celcius untuk mencegah peningkatan metabolisme mencit akibat kedinginan yang dapat berujung pada kematian. Air yang digunakan ialah air bersih yang diganti setiap hari. Udara dari pompa udara yang disalurkan melalui selang ke setiap ruangan kolam bertujuan untuk membuat mencit tetap bergerak selama masa berenang. Setelah berenang, mencit dikeringkan dengan handuk dan alat pengering rambut sebelum dimasukkan kembali dalam kandang.

Setelah 10 dan 28 hari, mencit dikorbankan dengan metode cervical dislocation dibawah pengaruh anastesia isofluran secara inhalasi. Setelahnya, jantung mencit diambil, dibersihkan dari darah dan jaringan lain dan ditimbang. Selanjutnya jantung mencit disimpan dalam cairan dapar/penyangga formalin 10\% sebelum diproses dalam pembuatan preparat histologi. Sediaan histologi diproses dengan cara blok parafin berisi jantung yang telah dipotong dan diletakkan dalam kaca obyek selanjutnya dilakukan proses penghilangan parafin dan kemudian diwarnai dengan pewarna Hematoxylin. Setelah dibilas dengan air, sediaan diberi pewarna Eosin.

Semua uji statistik dikomputerisasi menggunakan perangkat lunak SPSS 22.0. Hasil disajikan sebagai mean \pm standard deviation of mean (mean $+\mathrm{SD}$ ). Penggunaan One Way Annova sebagai analisis data berat jantung dan Tamhane's post hoc multiple comparison untuk melihat perbedaan antara signifikansi kelompok kontrol dengan aktifitas serta kelompok aktifitas dan latihan. Uji Fisher digunakan untuk menganalsis jenis gambaran histologis masingmasing kelompok. Untuk semua uji analisis, nilai $\alpha$ yang digunakan adalah 0,05 .

\section{HASIL}

Rerata berat jantung kelompok kontrol adalah $0,1330 \pm 0,02163$ gram kelompok aktifitas $0,2920 \pm 0,5891$, kelompok latihan $0,1450 \pm 0,02236$. Hasil menunjukkan terdapat perbedaan secara signifikan antara kelompok kontrol dan kelompok aktifitas $(p=0,009)$, serta antara kelompok aktifitas dan latihan fisik $(p=0,013)$.

Tabel 1. Hasil analisis berat jantung mencit

\begin{tabular}{lllll}
\hline & & N & Mean (SD) & P Value \\
\cline { 2 - 4 } Berat Jantung & Kontrol & 10 & $0,1330+0,02163^{*}$ & \\
\cline { 2 - 4 } & Aktifitas & 5 & $0,2920+0,05891^{\top \top}$ & $<0,001$ \\
\cline { 2 - 4 } & latihan & 20 & $0,1450 \pm 0,02236^{\top}$ & \\
\hline
\end{tabular}


*Berbeda secara signifikan, analisis post hoc menunjukkan p 0,009.

${ }^{+}$Berbeda secara signifikan, analisis post hoc menunjukkan p 0,013.

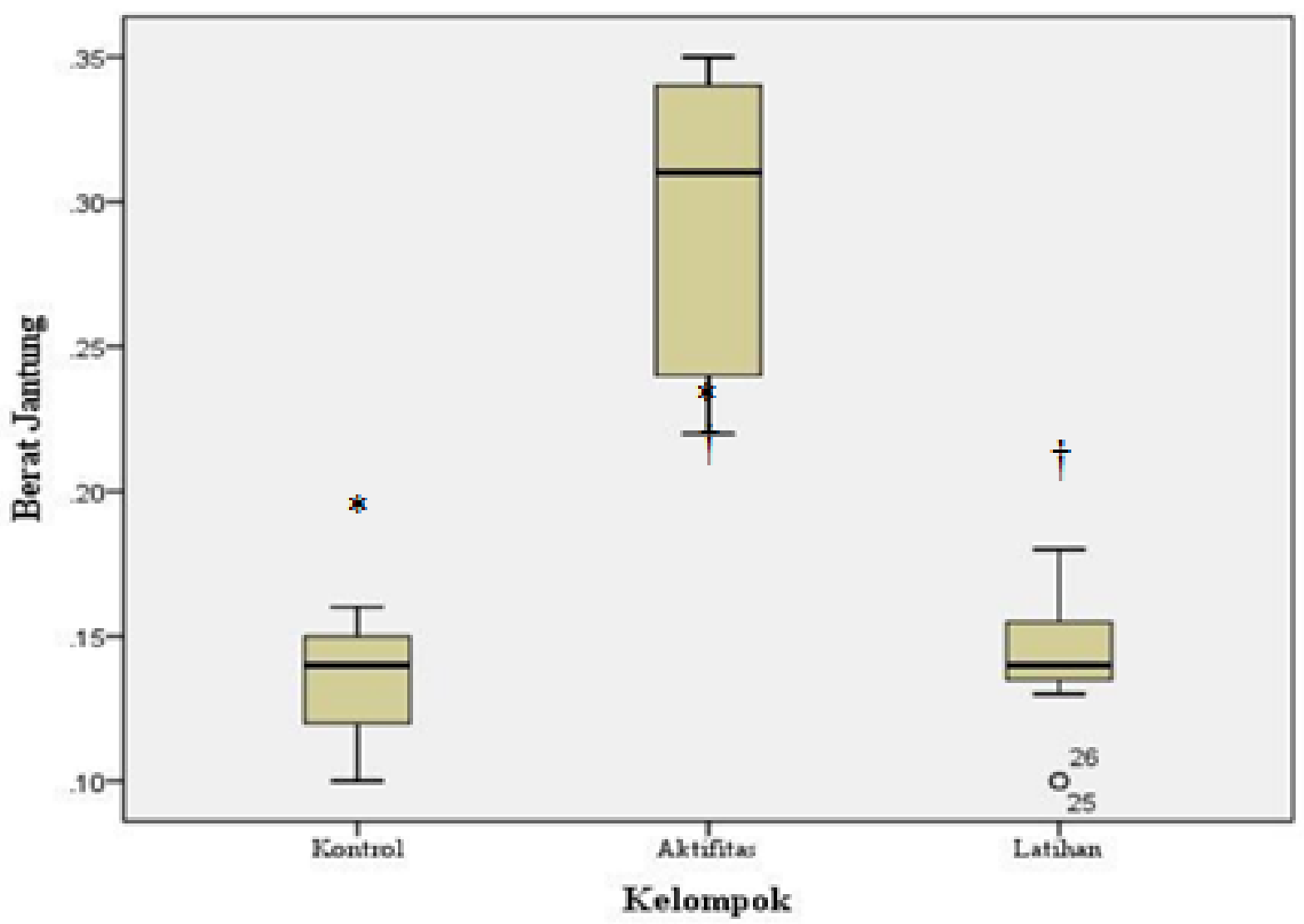

Gambar 2. Perbandingan berat jantung pada masing-masing kelompok.

Pengukuran rasio antara lebar miosit dibandingkan dengan berat jantung $(\mu \mathrm{m} / \mathrm{gr})$ setiap kelompok menunjukkan rasio sebesar $98,0383 \pm 26,10998$ untuk kelompok kontrol, $47,4643 \pm 20,32791$ untuk kelompok aktifitas, $103,7930 \pm 26,10886$. Hasil juga menunjukkan terdapat perbedaan secara signifikan antara kelompok kontrol dan kelompok aktifitas $(\mathrm{p}=0,006)$, serta antara kelompok aktifitas dan latihan fisik $(p=0,003)$.
Tabel 2. Hasil analisis gambaran histopatologi miokard antar kelompok.

\begin{tabular}{|c|c|c|c|}
\hline \multirow{2}{*}{$\begin{array}{c}\text { Kelompok } \\
\quad(\mathbf{n}=\mathbf{3 5})\end{array}$} & \multicolumn{2}{|c|}{$\begin{array}{c}\text { Variabel } \\
\text { Gambaran Hispatologi } \\
\text { Miokard }\end{array}$} & \multirow{2}{*}{ Nilai p } \\
\hline & $\begin{array}{c}\text { Normal } \\
\text { dan } \\
\text { Hipertrofi }\end{array}$ & $\begin{array}{l}\text { Iskemik dan } \\
\text { Infark }\end{array}$ & \\
\hline Kontrol & 10 & 0 & \multirow[b]{2}{*}{0,242} \\
\hline $\begin{array}{c}\text { Aktifitas } \\
\text { dan Latihan } \\
\text { Fisik }\end{array}$ & 0 & 25 & \\
\hline
\end{tabular}


Tabel 3. Hasil analisis gambaran histopatologi miokard kelompok kontrol dengan aktifitas fisik.

\begin{tabular}{|c|c|c|c|}
\hline \multirow[t]{2}{*}{ Kelompok $(n=15)$} & \multicolumn{2}{|c|}{$\begin{array}{c}\text { Variabel } \\
\text { Gambaran Hispatologi Miokard }\end{array}$} & \multirow[t]{2}{*}{ Nilai $p$} \\
\hline & Normal dan Hipertrofi & Iskemik dan Infark & \\
\hline Kontrol & 10 & 0 & \\
\hline $\begin{array}{c}\text { Aktifitas dan Latihan } \\
\text { Fisik }\end{array}$ & 3 & 2 & 0,095 \\
\hline
\end{tabular}

Tabel 4. Hasil analisis gambaran histopatologi miokard kelompok kontrol dengan latihan fisik.

\begin{tabular}{|c|c|c|c|}
\hline \multirow[t]{2}{*}{ Kelompok $(\mathbf{n}=30)$} & \multicolumn{2}{|c|}{$\begin{array}{c}\text { Variabel } \\
\text { Gambaran Hispatologi Miokard }\end{array}$} & \multirow[t]{2}{*}{ Nilai $p$} \\
\hline & Normal dan Hipertrofi & Iskemik dan Infark & \\
\hline Kontrol & 10 & 0 & \\
\hline Aktifitas dan Latihan Fisik & 18 & 2 & 0,437 \\
\hline
\end{tabular}

Gambaran histopatologi sel otot jantung pada kelompok yang dibagi menjadi kelompok kontrol serta aktifitas fisik dan latihan fisik menunjukkan perbedaan yang signifikan dengan nilai $\mathrm{p}$ sebesar 0,242 . Nilai $\mathrm{p}$ untuk gambaran histopatologi antara kelompok kontrol dengan kelompok aktifitas fisik ialah sebesar 0,095. Sedangkan untuk nilai $\mathrm{p}$ untuk gambaran histopatologi antara kelompok kontrol dengan kelompok aktifitas fisik ialah sebesar 0,437 . Hal ini menunjukkan bahwa gambaran histopatologi berupa gambaran patologis pada sel otot jantung terjadi pada mencit yang diberi perlakuan berupa aktifitas dan latihan fisik. Sedangkan mencit kelompok kontrol tidak menunjukkan adanya kondisi iskemik dan infark (Tabel 2,3,4 dan Gambar 3).
Gambaran histologi sel otot jantung pada kelompok kontrol tidak menunjukkan tandatanda hipertrofi maupun kondisi patologis lainnya. Pada kelompok aktifitas fisik, terdapat tanda miokard infark, begitu pula dengan kelompok latihan fisik terdapat gambaran miokard infark. 

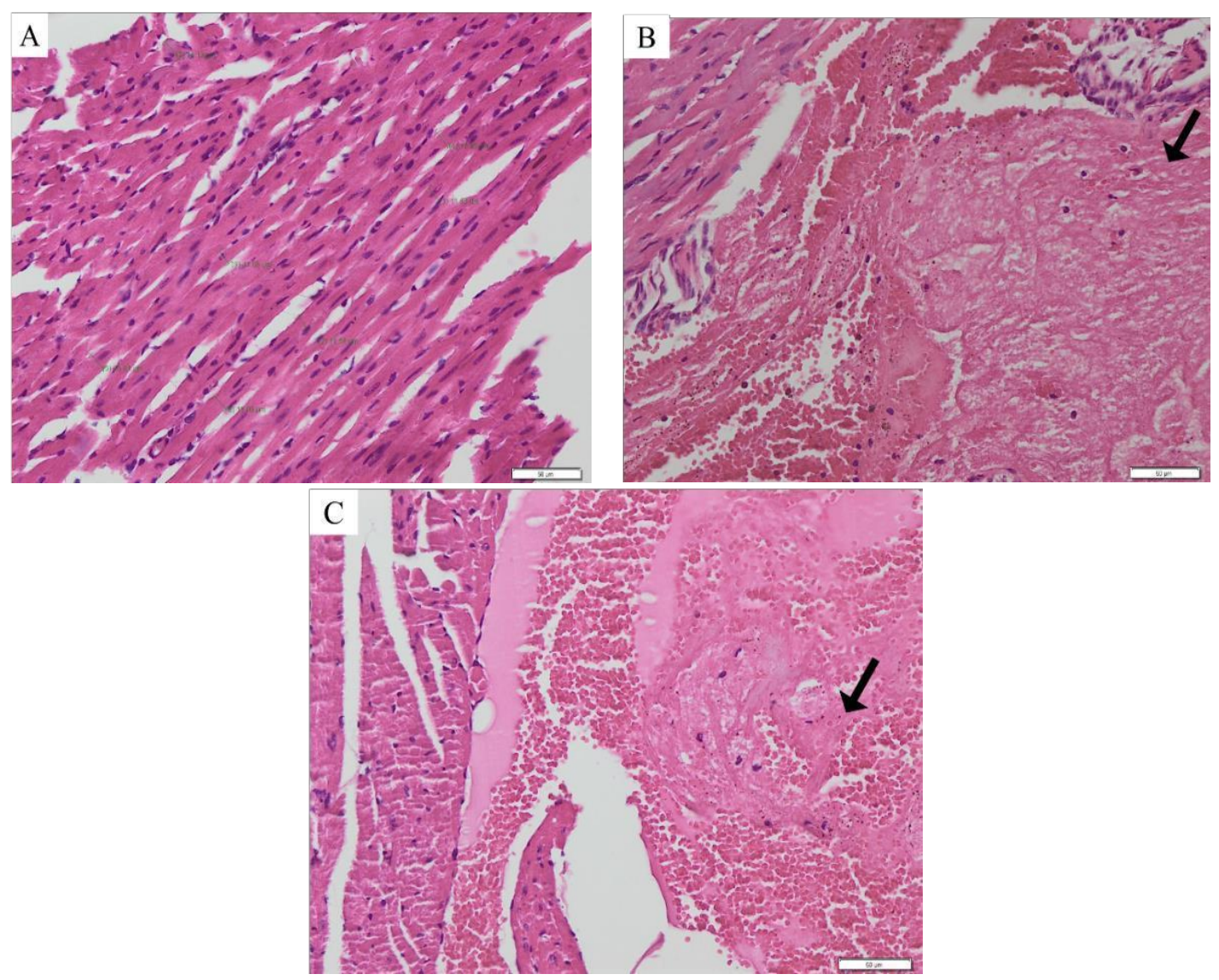

Gambar 3. Gambaran histologi; A. kelompok kontrol (normal); B. kelompok aktifitas fisik (miokard infark, panah menunjukkan miofibril yang rusak, meregang, bergelombang dan terlihat jarang-jarang); C. Kelompok latihan fisik (miokard infark, panah menunjukkan miofibril yang rusak, meregang, bergelombang dan terlihat jarang-jarang). 


\section{PEMBAHASAN}

Pencegahan penyakit kardiovaskular dapat dilakukan dengan menghindari faktor resiko penyakit tersebut. Latihan fisik aerobik dengan intensitas sedang yang dilakukan sekurang-kurangnya sekitar 30 menit selama minimal 5 hari dalam seminggu adalah salah satu cara yang dapat dilakukan sebagai upaya preventif pencegahan penyakit kardiovaskular 4. Selain menjadi upaya preventif, latihan fisik aerobik dengan intensitas sedang juga dapat menjadi pilihan untuk terapi pasien penyakit kardiovaskular selain terapi farmakologis 5 .

Berbeda dengan latihan fisik, aktifitas fisik cenderung meningkatkan resiko kondisi patologis pada jantung. Hal ini dapat disebabkan oleh pengaruh aktifitas yang cenderung tiba-tiba dan tidak berkesinambungan. Kondisi seperti ini akan meningkatkan beban jantung secara berlebihan dan dapat berujung pada gangguan suplai darah serta menimbulkan kerusakan jaringan jantung, khususnya sel otot jantung atau miosit ${ }^{9}$.

Pada penelitian yang menggunakan hewan coba berupa mencit usia dewasa yang diberi perlakuan berupa latihan fisik selama 4 minggu hanya mengalami peningkatan dalam massa ventrikel kiri, ratio massa ventrikel kiri dan berat badan mencit serta peningkatan tebal dinding jantung relatif ${ }^{7}$. Hal tersebut didukung pula dengan penelitian lain yang menunjukkan bahwa setelah diberi perlakuan berupa berlari selama 6 minggu terjadi hipertrofi ringan pada ventrikel kiri sebagai respon fisiologis yang ditandai dengan meningkatnya diameter ventrikel tanpa gambaran fibrosis yang mengindikasikan kondisi patologis ${ }^{8}$.

Namun, pada penelitian dengan menggunakan hewan penelitian berupa tikus galur wistar jantan menunjukkan hasil yang berbeda pada gambaran histologi miokardium setelah olahraga aktifitas fisik aerobik akut yaitu terjadinya hipertrofi miokard pada hari ke-3, gambaran iskemik miokard pada hari ke-7, dan gambaran infark miokard pada hari ke-10 9 .

Dalam penelitian ini, aktifitas fisik aerobik intensitas sedang selama 10 hari cenderung menunjukkan kondisi patologis pada jantung. Lain halnya dengan latihan fisik selama 28 hari aerobik intensitas sedang, hasil penelitan menunjukkan terjadinya perubahan jantung secara fisiologis berupa hipertrofi sel miokardium jantung. Bagaimanapun, tetap dibutuhkan penelitian selanjutnya mengenai efek dari aktifitas dan latihan fisik terhadap kesehatan kardiovaskuler. Penelitian ini sesuai dengan penelitian-penelitan sebelumnya, terutama penelitian mengenai efek latihan fisik terhadap kesehatan jantung.

\section{KESIMPULAN}

Aktifitas fisik aerobik dengan intensitas sedang dapat menyebabkan infark miokard dibandingkan dengan latihan fisik aerobik intensitas sedang pada mencit balb/c yang telah diberi perlakuan berupa berenang. Dibandingkan dengan aktifitas fisik, latihan fisik cenderung menunjukkan gambaran dan kondisi fisiologis jantung dalam beradaptasi terhadap peningkatan beban jantung selama perlakuan.

\section{PENDANAAN}

Penelitian ini didanai oleh program Hibah Internal Fakultas Kedokteran Universitas Padjadjaran tahun 2017.

\section{UCAPAN TERIMAKASIH}

Penulis berterimakasih kepada para laboran Laboratorium Farmakologi, Biokimia, Histologi, Biologi sel, Patologi Anatomi Fakultas Kedokteran Universitas Padjadjaran/ RSUP Dr. Hasan Sadikin atas bantuan dalam proses pengambilan dan pengolahan data dalam penelitian ini. Dan kepada pihak-pihak lain atas segala bantuan dan saran penulisan dalam penyusunan artikel jurnal ini.

\section{KONFLIK KEPENTINGAN}

Penulis menyatakan tidak terdapat potensi konflik kepentingan dengan penelitian, kepenulisan (authorship), dan atau publikasi artikel ini.

\section{DAFTAR PUSTAKA \\ 1. World Health Organization. Global status report on noncommunicable diseases 2014. World Heatlh Organization. 2014;176. \\ 2. World Health Organization. Cardiovascular diseases (CVDs). Cardiovascular diseases. 2016.}


3. World Health Organization. Noncommunicable Diseases (NCD) Country Profiles: Indonesia 2014. 2014;2014.

4. Golbidi S, Laher I. Exercise and the Cardiovascular System. Cardiol Res Pract. 2012;2012:15.

5. Piepoli MF, et al. 2016 European Guidelines on cardiovascular disease prevention in clinical practice The Sixth Joint Task Force of the European Society of Cardiology. Eur Heart J. 2016;37(29):2315-2381.

6. Golbidi S, Laher I. Exercise and the Aging Endothelium. $J$ Diabetes Res. 2013;2013.1-12.
7. Derumeaux G, et al. Myocardial alterations in senescent mice and effect of exercise training: a strain rate imaging study. Circ Cardiovasc Imaging. 2008;1(3):227-34.

8. Puhl S-L, et al. Exercise attenuates inflammation and limits scar thinning after myocardial infarction in mice. Am $J$ Physiol Heart Circ Physiol. 2015;309(2):H345-359

9. Flora R, Ferdinal F, Hernowo BS, Wanandi SI, Sadikin M, Freisleben HJ. Myocardial damage after continuous aerobic and anaerobic exercise in rats. Med J Indones. 2013;22(4):209-14. 